\title{
PENINGKATAN AKTIVITAS DAN HASIL BELAJAR SISWA DENGAN KOMBINASI MODEL PEMBELAJARAN KOOPERATIF JIGSAW DAN NUMBERED HEAD TOGETHER (NHT) PADA MATERI SISTEM EKSKRESI MANUSIA KELAS XI IPA 2 SMA NEGERI 5 MEDAN
}

\author{
Dewi Ratih , Erlintan Sinaga \\ Program Studi Pendidikan Biologi, Universitas Negeri Medan \\ *Email: ratihdewi481@gmail.com
}

\begin{abstract}
Abstrak
Penelitian ini bertujuan untuk meningkatkan aktivitas dan hasil Belajar Siswa dengan Kombinasi Model Kooperatif Jigsaw dan Numbered Head Together (NHT) pada Materi Sistem Ekskresi Manusia Kelas XI IPA 2 SMA Negeri 5 Medan Tahun Pembelajaran 2015/2016. Jenis penelitian ini adalah penelitian Tindakan Kelas (PTK) yang dilakukan dalam 2 siklus penelitian. Subjek penelitian ini adalah siswa kelas XI IPA 2 yang berjumlah 40 orang. Pada setiap siklus diadakan test hasil belajar dalam bentuk pilihan ganda berjumlah 30 soal. Hasil penelitian ini menunjukkan bahwa nilai rata-rata pre-test siswa diawal proses pembelajaran adalah 35,71, dengan ketuntasan belajar klasikal sebesar $0 \%$ (tidak ada nilai siswa yang mencapai KKM 70). Hasil belajar posttest siswa menunjukkkan terjadi peningkatan, dari hasil belajar siswa pada siklus I ke siklus II. Rata-rata hasil belajar post-test siswa pada siklus I adalah 64,19, terdapat 22 orang siswa yang tuntas mencapai KKM dan nilai ketuntasan klasikal 55\% (belum tuntas karena hal ini belum mencapai kriteria ketuntasan klasikal sebesar $\geq$ 85\%). Rata-rata hasil belajar siswa pada siklus II adalah 74,20, terdapat 34 orang siswa yang tuntas mencapai KKM dan nilai ketuntasan klasikal 85\% (tuntas, karena hal ini sudah mencapai kriteria ketuntasan klasikal sebesar $\geq 85 \%$ ). Terjadi peningkatan hasil belajar biologi siswa sebesar $30 \%$. Berdasarkan persentasi keaktifan belajar siswa pada siklus I dan siklus II, menunjukkkan terjadi peningkatan. Pada siklus I tingkat keaktifan siswa sebesar $60 \%$ meningkat menjadi $87,5 \%$ pada siklus II. Terjadi peningkatan hasil belajar biologi siswa sebesar 27,5\%. Dengan demikian diperoleh kesimpulan bahwa Kombinasi Model Kooperatif Jigsaw dan Numbered Head Together (NHT) dapat meningkatkan aktivitas dan hasil belajar biologi siswa di kelas XI IPA 2 SMA Negeri 2 Medan Tahun Pelajaran 2015/2016.
\end{abstract}

Kata Kunci: Hasil Belajar, Aktivitas Siswa, Model Jigsaw, Numbered Head Together (NHT), siklus, Sistem Ekskresi Manusia.

\begin{abstract}
This study aims to improve the activity and results of Student Learning with the Combination Model Cooperative Jigsaw and Numbered Head Together (NHT) on Human Excretion system Material Class XI IPA 2 SMA Negeri 5 Terrain Learning Year 2015/2016. This type of research is action research (PTK) done in two cycles of study. The subjects were students of class XI IPA 2 totaling 40 people. At each cycle is held test learning outcomes in the form of multiple choice questions numbered 30. The results of this study showed that the average value of the pre-test students at the beginning of the learning process is 35.71, with classical learning completeness $0 \%$ (no value students who achieve KKM 70). The results of post-test student learning, indicating an increase, of student learning outcomes in the first cycle to the second cycle. The average post-test learning outcomes of students in the first cycle was 64.19, there are 22 students who completed reached KKM and value of classical completeness 55\% (not yet complete because it has not reached the classical completeness criteria of $\geq 85 \%)$. The average results of students in the second cycle is 74.20 , there are 34 students who completed reached KKM and value of classical completeness $85 \%$ (complete, since it has already reached the criteria of classical completeness of $\geq 85 \%$ ). An increase in biology student learning outcomes by $30 \%$. As a percentage of the activity of students in the first cycle and the second cycle, indicating an increase. In the first cycle of students' level of activity of $60 \%$ increased to $87.5 \%$ in the second cycle. An increase in biology student learning outcomes by $27.5 \%$. Thus we concluded that the combination of Cooperative Model Jigsaw and Numbered Head Together (NHT) can improve biological activity and learning outcomes of students in class XI IPA 2 SMA Negeri 2 Medan in the academic year 2015/2016.
\end{abstract}

Keywords: Learning Outcomes, Student Activities, Model Jigsaw, Numbered Head Together (NHT), cycle, Human Excretion system. 


\section{PENDAHULUAN}

Dalam proses belajar mengajar, guru tentu harus dapat menyesuaikan model pembelajaran yang akan digunakan dengan kondisi dan suasana kelas. Penggunaan model pembelajaran yang monoton lebih cenderung menghasilkan kegiatan belajar mengajar yang membosankan bagi anak didik dan pengajaran pun akan tampak kaku. Anak didik akan terlihat kurang bersemangat belajar. Kejenuhan dan kemalasan sudah dipastikan akan menyelimuti kegiatan belajar anak didik. Ini berarti model pembelajaran yang ada tidak dapat difungsikan oleh guru sebagai alat motivasi dalam kegiatan belajar mengajar, dan menuntut guru untuk mencari jalan keluar lain.

Salah satu model pembelajaran yang dapat mengubah suasana pem-belajaran dengan melibatkan siswa adalah model pembelajaran kooperatif. Menurut Trianto (2011), bahwa pembelajaran kooperatif merupakan sebuah kelompok strategi pembelajaran yang melibatkan siswa bekerja sama secara berkolaborasi untuk mencapai tujuan bersama.

Dengan penggunaan kombinasi antara Jigsaw dengan Numbered Head Together (NHT) diharapkan dapat membuat siswa lebih aktif dan terlibat dalam proses pembelajaran. Sehingga dengan adanya model pembelajaran ini dapat meningkatkan efektivitas pengajaran yang diberikan oleh guru, memperbaiki cara belajar, secara tidak langsung akan meningkatkan hasil belajar siswa. Dalam penggunaan model pembelajaran ini, peneliti memilih materi sistem ekskresi karena materi ini menjelaskan tentang keterkaitan antara struktur, fungsi, dan proses serta kelainan/penyakit yang terjadi pada sistem ekskresi manusia.

Menurut Pramono (2015), menyatakan bahwa " Terdapat pengaruh kombinasi pembelajaran kooperatif tipe Jigsaw dan Numbered Head Together (NHT) terhadap keaktifan dan hasil belajar siswa dalam mata pelajaran IPA tentang pesawat sederhana. Dimana terdapat peningkatan $42 \%$ dari siklus I ke siklus II".

Dari hasil observasi dan wawancara peneliti dengan guru bidang studi Biologi SMA Negeri 5 Medan diperoleh informasi bahwa ditemukan beberapa kendala yang dihadapi dalam proses pembelajaran yaitu masih ada siswa mendapat nilai biologi dibawah rata-rata yaitu dibawah standar nilai yang sudah ditentukan. Adapun nilai standart yang harus dicapai di sekolah ini adalah (KKM) adalah 70. Di sekolah tersebut guru biologi sering memakai model kooperatif hanya saja pemilihan dan penggunaan model pembelajaran yang kurang menarik dan variatif dalam proses belajar mengajar. Sehingga siswa merasa bosan dan menjadi kurang aktif dalam proses belajar mengajar. Sebelumnya belum pernah diterapkan model pembelajaran dengan mengkombinasikan model pembelajaran, terlebih dalam Materi Pokok Sistem Ekskresi pada Manusia.

Berdasarkan uraian pada latar belakang masalah di atas maka peneliti melakukan penelitian dengan judul penelitian, "Peningkatan Aktivitas dan Hasil Belajar Siswa dengan Kombinasi Model Pembelajaran Kooperatif Jigsaw dan Numbered Head Together (NHT) pada Materi Sistem Ekskresi Manusia Kelas XI IPA 2 SMA Negeri 5 Medan Tahun Pelajaran 2015/2016".

Model pembelajaran merupakan suatu perencanaan atau suatu pola yang digunakan sebagai pedoman dalam merencanakan pembelajaran di kelas atau pembelajaran dalam tutorial dan untuk menentukan perangkatperangkat pembelajaran termasuk didalamnya buku-buku, film, komputer, kurikulum, dan lainlain. Model pembelajaran mempunyai makna yang lebih luas dari pada strategi, metode, prosedur dan pendekatan. Dalam model pembelajaran mencakup strategi pembelajaran yang digunakan, metode yang digunakan, dan pendekatan pengajaran yang digunakan yang lebih luas dan meyeluruh (Trianto, 2011).

Belajar kooperatif merupakan suatu metode pembelajaran dalam bentuk kelompok kecil. Siswa belajar dalam kelompok yang masingmasing anggotanya memiliki kemampuan yang berbeda-beda. Jumlah anggota kelompoknya antara empat sampai enam orang yang bekerjasama antara yang satu dengan yang lain dalam kegiatan belajaran (Alsa, 2010).

Menurut Trianto (2011), terdapat lima unsur penting dalam pembelajaran kooperatif, yaitu: (1) Saling ketergantungan yang bersifat positif antara siswa dalam bekerja sama mencapai tujuan; (2) Interaksi antar siswa yang semakin meningkat; (3) Tanggungjawab individualis dalam belajar kelompok; (4)Selain dituntut untuk mempelajari materi siswa juga dituntut untuk belajar berinteraksi dengan siswa lain; dan (5) Adanya kerjasama kelompok.

Menurut Hertiavi (2010), Pembelajaran kooperatif tipe Jigsaw merupakan salah satu tipe pembelajaran yang kooperatif dan fleksibel. Dalam pembelajaran tipe Jigsaw, siswa dibagi menjadi kelompok-kelompok yang anggotanya mempunyai karakteristik heterogen. Masing-masing siswa bertanggung jawab untuk mempelajari topik yang ditugaskan dan mengajarkan pada anggota 
kelompoknya, sehingga mereka dapat saling berinteraksi dan saling bantu.

Menurut Putriana (2008), pembelajaran tipe Numbered Head Together (NHT) dengan cara mengelompokkan siswa ke dalam kelompok kecil yang terdiri dari 3-5 orang. Pembelajaran tipe NHT memberikan kesempatan kepada siswa untuk saling membagikan ide-ide dan mempertimbangkan jawaban yang paling tepat. Selain itu, mendorong siswa untuk meningkatkan semangat kerja sama siswa.

Menurut Sudjana (2009), hasil belajar adalah kemampuan- kemampuan yang dimiliki setelah ia menerima pengalaman belajarnya. Dalam Sudjana, (2009) membagi-bagi macam hasil belajar, yakni (a) keterampilan dan kebiasaan, (b) pengetahuan dan pengertian, (c) sikap dan citacita. Masing-masing jenis hasil belajar dapat diisi dengan bahan yang telah ditetapkan dalam kurikulum.

Aktivitas merupakan salah satu faktor yang penting dalam pembelajaran. Aktivitas merupakan prinsip atau asa yang sangat penting di dalam interaksi belajar mengajar. Tanpa aktivitas, proses belajar tidak mungkin berlangsung dengan baik.

Di dalam tubuh makhluk hidup terjadi metabolisme yang di samping mengasilkan zat-zat berguna juga menghasilkan zat sisa. Zat-zat sisa ini tidak dibutuhkan lagi oleh tubuh. Proses pengeluaran zat-zat sisa dari dalam tubuh manusia dibedakan menjadi tiga macam, yakni defekasi, ekskresi, dan sekresi. (1) Defakasi, yaitu proses pengeluaran sisa-sisa pencernaan makanan yang disebut feses dan dikeluarkan melalui anus; (2) Ekskresi, yaitu pengeluaran zat-zat sisa metabolisme yang tidak dipakai oleh sel dan darah, dikeluarkan bersama urine, keringat, dan pernapasan; dan (3) Sekresi, yaitu proses pengeluaran getah oleh sel dan kelenjar. Getah yang dikeluarkan masih berguna untuk proses faal di dalam tubuh. Getah ini biasanya mengandung enzim.

\section{METODE PENELITIAN}

Jenis penelitian ini adalah penelitian tindakan kelas (Classroom Action Research). Prosedur Penelitian Tindakan Kelas (PTK) terdiri dari empat tahapan yang membentuk satu siklus, yaitu: (1) Perencanaan, tahapan perencanaan merupakan tahapan awal yang harus dilakukan peneliti sebelum melalukan sesuatu. Hal hal yang direncanakan diantaranya terkait dengan model pembelajaran, teknik pembelajaran, penyusunan rencana pembelajaran, pengadaan median dan penyusunan materi pembelajaran serta pembuatan tes hasil belajar; (2) Tindakan, penerapan dari perencanaan yang telah di buat yang dapat berupa suatu penerapan model pembelajaran tertentu yang bertujuan untuk memperbaiki atau menyempurnakan model yang sedang dijalankan; (3) Observasi, bersamaan dengan dilakukannya tindakan juga dilaksanakan observasi terhadap hasil tindakan yang telah dilakukan.

\section{HASIL PENELITIAN}

Tabel 1. Perbandingan Hasil Belajar Siswa pada Materi Sistem Ekskresi Manusia di kelas XI IA-2 SMA Negeri 5 Medan pada Siklus I dan Siklus II.

\begin{tabular}{cccc}
\hline No. & Tes Hasil Belajar & $\begin{array}{c}\text { Rata- } \\
\text { rata }\end{array}$ & $\begin{array}{c}\text { siswa } \\
\text { tuntas }\end{array}$ \\
\hline 1. & Post-test Siklus I & 64,19 & 22 Orang \\
2. & Post-test Siklus II & 74,20 & 32 Orang
\end{tabular}

Dari tabel diatas dapat diketahui bahwa terjadi peningkatan hasil belajar siswa pada siklus I dan siklus II, dimana pada post test siklus I ratarata siklus I rata-rata nilai yang diperoleh hanya 64,19 dinyatakan belum tuntas secara keseluruhan karena dibawah nilai KKM yaitu 70, siswa yang tuntas dalam belajar yaitu 22 orang siswa dari 40 orang siswa, sedangkan pada siklus II diperoleh rata-rata 74,20 dikatakan sudah tuntas karena secara keseluruhan mencapai KKM, dimana siswa yang tuntas dalam belajar yaitu 34 orang siswa. Selain itu, terjadi peningkatan aktivitas siswa dari siklus I dan siklus II dimana dari setiap aspek yang diamati terjadi peningkatan keaktifan, yaitu pada siklus I pada aktivitas melihat hanya 31 siswa yang aktif dengan persentase $77,5 \%$, meningkat pada siklus II menjadi 35 siswa yang aktif dengan persentase $87,5 \%$. Pada siklus I pada aktivitas berbicara hanya 10 siswa yang aktif dengan persentase $25 \%$. , meningkat pada siklus II menjadi 12 siswa yang aktif dengan persentase $30 \%$. Pada siklus I pada aktivitas mendengarkan hanya 15 siswa yang aktif dengan persentase 37,5\%., meningkat pada siklus II menjadi 23 siswa yang aktif dengan persentase $57,5 \%$. pada siklus I pada aktivitas menulis hanya 22 siswa yang aktif dengan persentase 55\%., meningkat pada siklus II menjadi 24 siswa yang aktif dengan persentase $60 \%$. 


\section{KESIMPULAN}

Peningkatan aktivitas belajar siswa dengan kombinasi model pembelajaran Jigsaw dan Numbered Head Together (NHT) pada materi sistem ekskresi manusia T.P. 2015/2016 pada siklus I aktivitas siswa belajar siswa secara klasikal sebesar $60 \%$ (cukup aktif), pada siklus II aktivitas belajar siswa klasikal sebesar 87,5\% (sangat aktif), terjadi peningkatan aktivitas belajar siswa sebesar $27,5 \%$.

Peningkatan hasil belajar siswa dengan kombinasi model pembelajaran kooperatif Jigsaw dan Numbered Head Together (NHT) pada materi sistem ekskresi manusia T.P. 2015/2016 pada siklus I rata-rata post-testnya adalah $55 \%$ (Rendah) pada siklus II rata-rata post-test adalah 85\% (Sedang). Terjadi peningkatan hasil belajar siswa sebesar $30 \%$.

\section{DAFTAR PUSTAKA}

Hertiavi, M. A., (2010), Penerapan Model Pembelajaran Kooperatif Tipe Jigsaw untuk peningkatkan kemampuan pemecahan masalah siswa SMP, Jurnal Pendidikan Universitas Negeri Semarang, Vol. 6, No. 5357.

Putriana, M. S., (2008), Peningkatan Proses dan Hasil Belajar Biologi pada Pokok Materi Ekosistem dengan Model Pembelajaran Kooperatif Tipe NHT pada siswa kelas VII SMP Negeri 2 Sidoharjo T.P. 2008/2009, Jurnal Pendidikan Universitas Muhammadiyah Surakarta.

Pramono,G. S., (2014), Peningkatan Keaktivan Berdiskusi Siswa dalam pembelajaran IPA tentang Pesawat Sederhana Melalui Kombinasi Model Jigsaw dengan NHT di kelas V SDN Margourip I Kecamatan Ngancar Kabupaten Kediri, Jurnal pendidikan universitas Nusantara PGRI Kediri.

Sudjana, (2009), Metoda Statistika,Tarsito, Bandung.

Trianto., (2011), Mendesain Model Pembelajaran Inovasi-Progresif, Kencana, Jakarta. 